\title{
Significant Role of Procalcitonin and Proinflammatory Markers in Diabetic Foot Ulcer Infections
}

\author{
Dr. Ghanshyam Gahlot ${ }^{1}$, Dr. Poonma Ram ${ }^{2}$, Dr. Dinesh Parmar ${ }^{* 3}$, Dr. Manoj Garg ${ }^{4}$, \\ Dr. Prakash Hundekar ${ }^{5}$, Dr. R. K. Aseri ${ }^{6}$, Dr. B. L. Mansuriya ${ }^{7}$, Dr. Surendra Kumar ${ }^{8}$ \\ ${ }^{1}$ Senior Demonstrator, Department of Biochemistry, Govt. Medical College, Barmer, Rajasthan, India \\ ${ }^{2}$ Senior Resident, Department of Radiology, Govt. Medical College, Barmer, Rajasthan, India \\ ${ }^{3}$ Associate Professor \& Head, Department of Medicine, Govt. Medical College, Barmer, Rajasthan, India \\ ${ }^{4}$ Associate Professor, Deputy Director (RajMES), Department of Forensic Medicine, S.P. Medical College, \\ Bikaner, Rajasthan, India \\ ${ }^{5}$ Professor \& Head, Department of Biochemistry, Govt. Medical College, Barmer, Rajasthan, India \\ ${ }^{6}$ Principal and Controller, Govt. Medical College, Barmer, Rajasthan, India \\ ${ }^{7}$ Medical Superintendent, Govt. Medical College and Associated Group of Hospitals, Barmer, Rajasthan, India \\ ${ }^{8}$ Additional Principal \& Sr. Professor, Department of Medicine, S.P. Medical college, Bikaner, Rajasthan, India
}

*Correspondence Author: Dr. Dinesh Parmar; drdinesh4u@yahoo.com

Received 20 August 2021;

Accepted 20 September 2021;

Published 01 October 2021

\begin{abstract}
Background: Procalcitonin (PCT), an amino acid protein precursor of calcitonin hormone released by thyroid C cells or other body cells, can be used as a marker for diagnosing infection. PCT has a suggestive role in diagnosing diabetic foot infection alone or in combination with other markers of infection. Aim: We aimed to evaluate the roles of interleukin-6 (IL-6), CRP, and PCT levels in the differential diagnosis of the patients with infected diabetic foot ulcer (IDFU) and non-infected diabetic foot ulcer (NIDFU) and to compare those with C-reactive protein (CRP), white blood cell (WBC), and erythrocyte sedimentation rate (ESR). Methods: A total of 95 subjects with DFU and NIDFU were enrolled. WBC count, ESR, CRP, and PCT were done for all subjects at admission after obtaining informed consent. Patients over 18 years with a diagnosis of type 2 diabetes mellitus and DFU who were followed up in our hospital were included in the study. In addition to this patient group, patients with diabetes but without DFU were determined as the control group. Results: Twenty nine patients with IDFU, 29 patients with NIDFU, and 43 patients as the control group were included in the study. Fifty-six point three percent of the patients who participated in the study were males, and the mean age was $62.87 \pm 10.99$ years. WBC, ESR, CRP, and IL-6 levels of the cases with IDFU were determined to be significantly higher compared to the cases in NIDFU ( $\mathrm{p}<0.001$ ). The area under the ROC curve (AUROC) value was highest for CRP ( $\mathrm{p}$ $<0.001$ ), and the best cut-off value for CRP was $36 \mathrm{~m} / \mathrm{L}$. The best cut-off values for IL-6, ESR, and WBC were $109.4 \mathrm{pg} / \mathrm{mL}, 53 \mathrm{~mm} / \mathrm{h}$, and 13.7 $(103 \mu / \mathrm{L})$, respectively. Conclusion: Serum PCT levels were not found to be effective in the discrimination of IDFU and NIDFU. Serum IL-6 level seems to be one promising inflammatory markers in the discrimination of IDFU. Based on our results, we conclude that PCT has a valuable role in diagnosing infection in DFUs.
\end{abstract}

Keywords: Diabetic Foot Ulcer Infection, Inflammatory Markers, Procalcitonin

\section{Introduction}

Diabetic foot infection (DFI) is one of the most feared complications of Diabetes mellitus (DM) ${ }^{[1,2]}$. Diabetic foot disease presents in various ways such as ulcer, infection/abscess, and gangrene ${ }^{[3]}$. About $15 \%$ of people with diabetes will develop a foot ulcer at some time during their life, and $85 \%$ of major leg amputations begin with a foot ulcer ${ }^{[4,5]}$. Most of DFIs are polymicrobial ${ }^{[6]}$, gram-positive bacteria, such as Staphylococcus aureus (S. aureus) and coagulase negative staphylococci are the most common pathogens ${ }^{[7]}$. Foot infection in diabetic patients is a gradually increasing problem, and it can cause severe sequelae ${ }^{[8]}$. Infected diabetic foot ulcer (IDFU) usually develops based on the presence of skin ulceration after peripheral neuropathy or trauma. The wound is colonized by many microorganisms, and they may penetrate down to the deeper tissues and bone in consequence of the spread of infection. In cases of a progression of infection, the hospitalization of the patients, surgical resection, and amputation may be required ${ }^{[9]}$. Unfortunately, the life quality of patients undergoing lower extremity amputation is quite poor, and the five year mortality is similar to that of some of the most mortal cancer types ${ }^{[10]}$. 
In a patient with a diabetic foot wound, first, the presence of infection should be assessed, and if present, the severity of the infection should be classified ${ }^{[11]}$. The classification systems of the Infectious Diseases Society of America (IDSA) and the International Working Group on the Diabetic Foot (IWGDF) are used to determine the severity of infection ${ }^{[12]}$. In the studies performed, the classification schemes used to detect the infection were found to be effective for prognosis and for the need for amputation in patients with diabetic foot ulcers ${ }^{[13-14]}$.

An IDFU diagnosis should not be based on microbiological findings; clinical findings should also be used in the diagnosis ${ }^{[15,16]}$. Since infection may rapidly deteriorate the patient's condition ${ }^{[17]}$, it is necessary to diagnose IDFU rapidly ${ }^{[18]}$. However, always, it is not easy to diagnose IDFU ${ }^{[19]}$. Despite the presence of severe diabetic infection, an elevation in body temperature and leukocyte levels and in the erythrocyte sedimentation rate (ESR) may not be observed ${ }^{[20]}$.

Procalcitonin (PCT) is the protein precursor of calcitonin, synthesized and released by C-cells in the thyroid gland. It is suggested that PCT production after inflammation is performed by the liver and peripheral blood mononuclear cells and is modulated by lipopolysaccharides and sepsis related cytokines. It is also reported that PCT is a more accurate marker for a differential diagnosis of bacterial infections compared to C-reactive protein (CRP) ${ }^{[21]}$. Some studies have shown that serum PCT levels might play a role in the differential diagnosis of IDFU ${ }^{[22-24]}$. But, in another study, the role of serum PCT levels in the treatment and follow-up of infected ulcers was primarily evaluated, and then, it was reported that it had no role in the discrimination of diabetic ulcers with mild to moderate infection and severe infection ${ }^{[25]}$.

Interleukin-6 (IL-6) is one of the proinflammatory cytokines that can be detected in serum in the early stages of infection. It plays a critical role, especially in the induction of CRP and fibrinogen synthesis in the liver during the course of bacterial infection. Therefore, it was suggested that this cytokine could increase earlier than CRP during bacterial infection and that it could enable an earlier diagnosis ${ }^{[26,27]}$. There are a limited number of studies evaluating the role of serum IL-6 levels in diabetic ulcers ${ }^{[28]}$. Fibrinogen and fibrin play important roles in blood clotting, fibrinolysis, cellular and matrix interactions, inflammation, wound healing, and neoplasia ${ }^{[29]}$.

Since there is a limited number of studies related to the use of serum IL-6, and PCT levels in the diagnosis of IDFU and the results obtained are also contradictory, more advanced studies are needed on this subject. In this study, we also aimed to evaluate the roles of serum IL-6, and PCT levels in the differential diagnosis both of patients with IDFU and of those with non-infected diabetic foot ulcers (NIDFU) and to compare those with other commonly used inflammatory markers like CRP, white blood cell (WBC), and ESR.

\section{Materials and Methods}

Patients over 18 years of age with a diagnosis of type 2 diabetes mellitus and diabetic foot ulcer and who were followed-up in infectious disease, internal medicine, surgery, and Diabetic Research Centre P.B.M. Hospital were included in the study.

In addition to this patient group, patients with diabetes but without DFU were determined as the control group. The study was approved by the local ethics committee, and each patient was included in the study after obtaining written consent and then was informed about the study.
Patients were assessed regarding IDFU by a team including infectious disease specialists, internal medicine specialists, and surgeons. The presence of purulent discharge or two or more findings of inflammation (erythema, local warmth, local tenderness, pain, and in duration) in diabetic ulcer were considered to be evidence of infection. Discrimination of IDFU and NIDFU was performed according to Infectious Diseases Society of America guidelines ${ }^{[30]}$. The patients followed up with the diagnosis of type 2 diabetes mellitus and who had no diabetic foot ulcer were determined to be the control group.

The following patients were not included in the study: the patients with other systemic or localized infectious diseases like sepsis, urinary system infection, pneumonia, and meningitis; the patients with a history of surgery within the last 6 weeks; the patients with hematological or solid malignancies; the patients with systemic inflammatory diseases like inflammatory bowel disease; the patients with rheumatoid arthritis or other rheumatic diseases; and the patients receiving ongoing immunosuppressive treatment and who received efficacious anti-biotherapy earlier.

Demographic data, duration of diabetes, drugs used related to diabetes, concomitant diseases, depth of wound (superficial or deep), localization of wound (toe, metatarsal, or midfoot/heel), presence of purulent discharge, a positive probe-tobone test, history of antibiotic use, and presence of fever were noted during admittance. Culture specimens for microbiological analysis were taken with deep tissue sampling. Magnetic resonance imaging (MRI) was performed in patients requiring imaging examination. Blood samples were taken after 8-10 hours of overnight fasting, and complete blood count, ESR, HbAlc, fasting blood glucose, CRP, PCT, and IL-6 levels were studied. Complete blood count, ESR, HbA1c, fasting blood glucose, CRP, and fibrinogen levels were studied on the same day. Blood specimens for serum PCT and IL-6 levels were centrifuged at $4000 \mathrm{rpm}$ for 10 minutes after storage for 30-60 minutes. Serum samples obtained were stored at $-80^{\circ} \mathrm{C}$ until biochemical analyses were performed. Serum interleukin- 6 measurements were performed by using a Human IL-6 Elisa kit (Sigma Aldrich, USA). Absorbance readings were performed by using an Automated EIA and Chemistry Analyzer. Results were reported as $\mathrm{pg} / \mathrm{mL}$. Serum PCT measurements were performed by using a Immunoassay Analyzer (ROCHE), the electrochemiluminescence immunoassay (ECLIA) method, and Roche Diagnostics kit. The reference intervals of serum PCT levels were $0-0.05 \mathrm{ng} / \mathrm{mL}$. Serum complete blood count, ESR, HbA1c, fasting blood glucose, and CRP levels were studied in the biochemistry laboratory of our hospital. All tests were performed in a blinded manner.

Statistical analysis: Statistical analyses were performed using the software package SPSS for Windows version 16.0.0 (SPSS Inc., Chicago, Illinois). The Mann-Whitney U test or Kruskal-Wallis test were used to compare the continuous variables. To assess the correlation between the grade of infection severity and laboratory parameters, Spearman rho correlation coefficients were calculated for patients with no associated infectious diseases, to avoid the effect of other causes of infection. Comparisons of the correlation coefficients were performed with the Z-test, using the Fisher's Z transformation. A receiver operating characteristic (ROC) analysis and the area under the ROC curve (AUC) were calculated to measure the accuracy of the laboratory parameter to distinguish patients with IDFU from patients with IDFU $+\mathrm{O}$. The best cut-off value was calculated, and specificity and sensitivity of the laboratory parameters were determined using the best cut-off value. Comparison of the ROC curves was performed to compare 
the accuracies of laboratory markers for distinguishing the grades of infection severity. A P value $<0.05$ was considered statistically significant. Pearson's chi-square test and the Fisher-FreemanHalton test were used for the comparison of qualitative data. Diagnostic screening tests (sensitivity, specificity, positive predictive value, and negative predictive value) and ROC curve analysis were applied for the determination of cut-off points for parameters. Significance was evaluated at a level of $p<005$.

\section{Results}

Twenty-nine patients with IDFU, 29 patients with NIDFU, and 43 patients as the control group were included in the study. Seventy seven point eighty nine percent of the patients $(n=74)$ who participated in the study were males, and the mean age was determined to be $62.87 \pm 10.99$ years. Demographic data of the patients who participated in the study are shown in Table 1 . Wound characteristics in the groups with IDFU and NIDFU are shown in Table 2. A positive probe-to-bone test was observed in a total of 10 cases, and osteomyelitis was determined in 4 of these cases with MRI. We detected the characteristic findings of diabetic foot osteomyelitis on MRI, decreased signal intensity of the affected bone on T1- weighted images and increased intensity on T2weighted and post contrast images, in these patients. Deep tissue culture was taken from 14 cases with IDFU, and microbial growth was detected in $10(50.8 \%)$ of them. The results of microbial growth were as follows: S.aureus in 5 cases, $\mathrm{P}$. aeruginosa in 3 cases, E. cloacae and E. coli in 2 case, Streptococcus spp. in 2 case, and P. vulgaris in 2 case. The results related to inflammatory markers in the groups included in the study are shown in Table 3.
WBC levels of the cases with IDFU were determined to be significantly higher compared to the cases in NIDFU ( $p<001)$ and diabetic control groups. ESR values of the cases with IDFU were determined to be significantly higher compared to the cases with NIDFU ( $p<0.001)$ and diabetic control groups. ESR values of the cases with NIDFU were determined to be significantly higher compared to the cases in the diabetic control group ( $p<0 \quad 01$ ). Serum CRP levels of the cases with IDFU were determined to be significantly higher compared to the cases with NIDFU ( $p<0$ 01) and diabetic control groups ( $\mathrm{p}<001)$.

Serum CRP levels of the cases with NIDFU were determined to be significantly higher compared to the cases in the diabetic control group $(\mathrm{p}<001)$.

Serum IL-6 levels of the cases with IDFU were determined to be significantly higher compared to the cases with NIDFU ( $p<0.001)$ and diabetic control groups ( $p<0.001)$. Serum IL-6 levels of the cases with NIDFU were determined to be significantly higher compared to the cases in the diabetic control group ( $\mathrm{p}<0.001$ ). No statistically significant difference was determined between serum PCT measurements of the cases with IDFU compared to the cases with NIDFU ( $p>0.05)$ and the cases in the diabetic control group ( $p>0.05$ ).

The area under the ROC curve (AUROC) was measured to estimate the presence of bacterial infection in the cases with diabetic ulcer (Figure 1). AUROC value was highest for CRP (0.989; $\mathrm{p}<0.001)$, followed by ESR (0.972; $\mathrm{p}<0.001)$, IL-6 (0.912; $\mathrm{p}<0.001)$ and WBC $(0.868 ; \mathrm{p}<0.001)$, respectively. The best cutoff values for CRP, IL-6, ESR, and WBC were $36 \mathrm{mg} / \mathrm{L}, 109.4$ $\mathrm{pg} / \mathrm{mL}, 53 \mathrm{~mm} / \mathrm{h}$, and $13.7(103 \mu / \mathrm{L})$, respectively. Maximum sensitivity, specificity, and positive and negative predictive values are shown in Table 4.

Table 1: Demographic characteristics of the patients

\begin{tabular}{|c|c|c|c|c|c|}
\hline Characteristics & Total & DFI $(n=29)$ & NDFI $(n=29)$ & Control $(n=37)$ & $p$ \\
\hline Age (year) Min - max (median) Mean \pm SD & $\begin{array}{l}36-79(59) \\
62.87 \pm 10.99\end{array}$ & $\begin{array}{l}42-79(62) \\
63.97 \pm 11.49\end{array}$ & $\begin{array}{l}39-72(66) \\
63.24 \pm 11.87\end{array}$ & $\begin{array}{l}33-82(57) \\
59.35 \pm 11.48\end{array}$ & 0.138 \\
\hline Gender, $n(\%)$ Male & $74(77.89)$ & $22(75.86)$ & $24(82.76)$ & $28(75.68)$ & \\
\hline Female & $21(22.11)$ & $7(24.14)$ & $5(17.24)$ & $9(24.32)$ & 0.004 \\
\hline $\begin{array}{l}\text { Duration of diabetes (year) Min-max (median) } \\
\text { Mean } \pm \text { SD }\end{array}$ & $\begin{array}{l}1-35(11) \\
10.68 \pm 8.83\end{array}$ & $\begin{array}{l}3-30(16) \\
15.15 \pm 9.65\end{array}$ & $\begin{array}{l}2-32(19) \\
15.67 \pm 9.30\end{array}$ & $\begin{array}{l}1-23(8) \\
8.92 \pm 6.66\end{array}$ & 0.001 \\
\hline Use of insulin, $n(\%)$ Absent & $48(50.53)$ & $5(23.7)$ & $8(26.3)$ & $35(76.7)$ & \\
\hline Present & $47(49.47)$ & $24(76.3)$ & $21(73.7)$ & $2(23.3)$ & 0.001 \\
\hline Use of oral antidiabetic, $n(\%)$ Absent & $49(51.58)$ & $19(65.52)$ & $21(72.41)$ & $9(24.32)$ & \\
\hline Present & $46(48.42)$ & $10(34.49)$ & $8(27.59)$ & $28(75.68)$ & 0.001 \\
\hline Not receiving antidiabetic No & $78(82.11)$ & $21(72.41)$ & $25(86.21)$ & $32(86.49)$ & \\
\hline treatment, $n(\%)$ Yes & $17(17.89)$ & $8(27.59)$ & $4(13.79)$ & $5(13.51)$ & 0.079 \\
\hline Hypertension, $n(\%)$ Absent & $43(45.26)$ & $8(27.59)$ & $13(44.83)$ & $14(37.84)$ & \\
\hline Present & $52(54.74)$ & $21(72.41)$ & $16(55.17)$ & $15(40.54)$ & 0.094 \\
\hline Cerebrovascular accident, $n(\%)$ Absent & $90(94.74)$ & $28(96.55)$ & $27(93.10)$ & $35(95.60)$ & \\
\hline Present & $5(5.26)$ & $1(3.45)$ & $2(6.90)$ & $2(5.40)$ & 0.706 \\
\hline Peripheral vascular disease, $n(\%)$ Absent & $83(87.37)$ & $21(72.41)$ & $25(86.21)$ & $37(100.0)$ & \\
\hline Present & $12(12.63)$ & $8(27.59)$ & $4(13.79)$ & $0(0.0)$ & 0.001 \\
\hline Chronic obstructive pulmonary Absent & $87(91.58)$ & $25(86.21)$ & $27(93.10)$ & $35(95.60)$ & \\
\hline disease, $n(\%)$ Present & $8(8.42)$ & $4(13.79)$ & $2(6.90)$ & $2(5.40)$ & 0.193 \\
\hline Chronic renal failure, $n(\%)$ Absent & $88(92.63)$ & $25(86.21)$ & $28(96.55)$ & $35(95.60)$ & \\
\hline Present & $7(7.37)$ & $4(13.79)$ & $1(3.45)$ & $2(5.40)$ & 0.841 \\
\hline Coronary artery disease, $n(\%)$ Absent & $46(48.42)$ & $19(65.52)$ & $25(86.21)$ & $28(75.68)$ & \\
\hline Present & $49(51.58)$ & $10(34.49)$ & $4(13.79)$ & $9(24.32)$ & 0.233 \\
\hline $\begin{array}{l}\text { Fasting blood glucose Min-max (median) } \\
\text { Mean } \pm \text { SD }\end{array}$ & $\begin{array}{l}63-689(201) \\
211.72 \pm 123.88\end{array}$ & $\begin{array}{l}89-710(241.5) \\
263.82 \pm 158.26\end{array}$ & $\begin{array}{l}65-498(185) \\
243.10 \pm 125.28\end{array}$ & $\begin{array}{l}64-321(132) \\
149.87 \pm 79.89\end{array}$ & 0.001 \\
\hline $\begin{array}{l}\text { HbA1c Min-max (median) } \\
\text { Mean } \pm \text { SD }\end{array}$ & $\begin{array}{l}5.60-18(9) \\
9.13 \pm 2.54\end{array}$ & $\begin{array}{l}6.9-14.8(9.8) \\
9.55 \pm 1.68\end{array}$ & $\begin{array}{l}5.7-21(10.85) \\
9.89 \pm 2.77\end{array}$ & $\begin{array}{l}5.9-11.8(7.4) \\
9.23 \pm 2.23\end{array}$ & 0.003 \\
\hline
\end{tabular}


Table 2: Evaluation of wound characteristics in the groups with diabetic ulcer

\begin{tabular}{|l|l|l|l|l|}
\hline \multicolumn{2}{|l|}{ Characteristics } & $\begin{array}{l}\text { Total }(n=58) \\
n(\%)\end{array}$ & $\begin{array}{l}\text { DFI }(n=29) \\
n(\%)\end{array}$ & $\begin{array}{l}\text { NDFI }(n=29) \\
n(\%)\end{array}$ \\
\hline \multirow{3}{*}{ Localization of ulcer } & Toe & $7(24.14)$ & $7(24.14)$ & $10(34.48)$ \\
\cline { 2 - 5 } & Metatarsal & $13(44.83)$ & $16(55.17)$ & $12(41.38)$ \\
\cline { 2 - 5 } & Midfoot/ heel & $9(31.03)$ & $6(20.69)$ & $7(24.14)$ \\
\hline \multirow{3}{*}{ Depth of ulcer } & Superficial & $21(72.41)$ & $15(51.72)$ & $25(86.21)$ \\
\cline { 2 - 5 } & Deep & $9(31.03)$ & $14(48.28)$ & $4(13.79)$ \\
\hline Secretion & No & $19(65.51)$ & $16(55.17)$ & $29(100.0)$ \\
\hline \multirow{3}{*}{ Positive probe-to-bone test } & Yes & $10(34.48)$ & $13(44.83)$ & $0(0.0)$ \\
\cline { 2 - 5 } & No & $19(65.51)$ & $21(72.41)$ & $29(100.0)$ \\
\cline { 2 - 5 } & Yes & $10(34.48)$ & $8(27.59)$ & $0(0.0)$ \\
\cline { 2 - 5 } & No & $22(75.86)$ & $21(72.41)$ & $0(0.0)$ \\
\hline Fever & No & $7(24.14)$ & $19(65.52)$ & $29(100.0)$ \\
\cline { 2 - 5 } & Yes & $6(20.69)$ & $10(34.48)$ & $0(0.0)$ \\
\hline
\end{tabular}

Table 3: Inflammatory Markers in Infected Diabetic Foot Ulcer (DFI), Non Infected Diabetic Foot Ulcer (NDFI), and Control groups

\begin{tabular}{|c|c|c|c|c|c|c|c|c|}
\hline \multirow{2}{*}{$\begin{array}{l}\text { WBC } \\
\text { Min-max } \\
\text { (median) } \\
\text { Mean } \pm \text { SD }\end{array}$} & Total & ${ }^{1}$ DFI $(n=38)$ & ${ }^{2}$ NDFI $(n=38)$ & ${ }^{3}$ Control $(n=43)$ & $\mathbf{p}$ & ${ }^{1-2} p$ & $1-3 p$ & $2-3 p$ \\
\hline & $\begin{array}{l}3.8-45.1(8.9) \\
9.8 \pm 4.8\end{array}$ & $\begin{array}{l}5-61.2(2) \\
14.6 \pm 6.8\end{array}$ & $\begin{array}{l}4-16.3(10) \\
8 \pm 3.1\end{array}$ & $\begin{array}{l}5.1-13.7(9.1) \\
9.1 \pm 3\end{array}$ & 0.001 & 0.001 & 0.001 & 0.468 \\
\hline \multirow{2}{*}{$\begin{array}{l}\text { ESR } \\
\text { Min-max } \\
\text { (median) } \\
\text { Mean } \pm \text { SD }\end{array}$} & & & & & & & & \\
\hline & $\begin{array}{l}3-114(27) \\
33.87 \pm 35.79\end{array}$ & $\begin{array}{l}7-129(66.5) \\
68.34 \pm 34.68\end{array}$ & $\begin{array}{l}3-71(29) \\
37.21 \pm 18.44\end{array}$ & $\begin{array}{l}3-40(13) \\
16.02 \pm 8.98\end{array}$ & 0.001 & 0.001 & 0.001 & 0.001 \\
\hline \multirow{2}{*}{$\begin{array}{l}\text { CRP } \\
\text { Min-max } \\
\text { (median) } \\
\text { Mean } \pm \text { SD }\end{array}$} & & & & & & & & \\
\hline & $\begin{array}{l}0.6-401(7.9) \\
79.49 \pm 102.35\end{array}$ & $\begin{array}{l}31-451(195) \\
198.17 \pm 81.36\end{array}$ & $\begin{array}{l}0.7-52(10.1) \\
13.52 \pm 9.53\end{array}$ & $\begin{array}{l}0.9-10.5(3.7) \\
4.37 \pm 3.8\end{array}$ & 0.001 & 0.001 & 0.001 & 0.001 \\
\hline \multirow{2}{*}{$\begin{array}{l}\text { IL-6 } \\
\text { Min-max } \\
\text { (median) } \\
\text { Mean } \pm \text { SD }\end{array}$} & & & & & & & & \\
\hline & $\begin{array}{l}5.4-1897.9(50.8) \\
186.22 \pm 291.15\end{array}$ & $\begin{array}{l}32.7-1823.9(120.4) \\
245.12 \pm 391.98\end{array}$ & $\begin{array}{l}7.8-606.7(42.35) \\
64.81 \pm 97.29\end{array}$ & $\begin{array}{l}5.4-172.2(34.4) \\
39.18 \pm 34.87\end{array}$ & 0.001 & 0.001 & 0.001 & 0.003 \\
\hline \multirow{2}{*}{$\begin{array}{l}\text { PCT } \\
\text { Min-max } \\
\text { (median) } \\
\text { Mean } \pm \text { SD }\end{array}$} & & & & & & & & \\
\hline & $\begin{array}{l}0.03-12.40(0.16) \\
0.34 \pm 0.97\end{array}$ & $\begin{array}{l}0.03-12.9(0.16) \\
0.6 \pm 1.9\end{array}$ & $\begin{array}{l}0.03-0.51(0.13) \\
0.19 \pm 0.09\end{array}$ & $\begin{array}{l}0.05-0.74(0.19) \\
0.20 \pm 0.15\end{array}$ & 0.387 & 0364 & 0.658 & 0.543 \\
\hline
\end{tabular}

Table 4: Sensitivity, specificity, negative predictive value, and positive predictive value of inflammatory marker

\begin{tabular}{|l|l|l|l|l|l|}
\hline Parameters & Cut-off & Sensitivity & Specificity & Positive predictive value & Negative predictive value \\
\hline CRP $(\mathbf{m g} / \mathbf{L})$ & $\geq 36$ & 100.00 & 98.45 & 98.51 & 100.00 \\
\hline IL-6 $(\mathbf{p g} / \mathbf{m L})$ & $\geq 109.4$ & 78.84 & 96.87 & 97.62 & 83.00 \\
\hline ESR $(\mathbf{m m} / \mathbf{h})$ & $\geq 53$ & 76.68 & 91.24 & 89.49 & 81.30 \\
\hline WBC $\left(\mathbf{1 0}^{\mathbf{3}} \boldsymbol{\mu} / \mathbf{L}\right)$ & $\geq 13.7$ & 81.05 & 94.84 & 89.20 & 85.00 \\
\hline
\end{tabular}

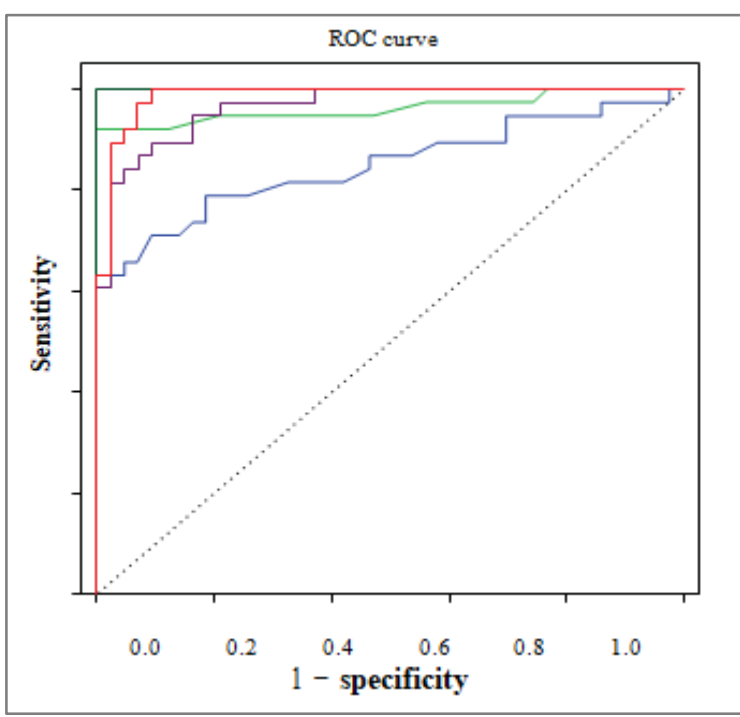

Figure 1: Receiver operating characteristic curves of inflammatory markers 


\section{Discussion}

The role of various inflammatory markers like WBC, ESR, CRP, PCT, and IL-6 in the discrimination of IDFU was evaluated in this study. It was shown that all inflammatory markers evaluated in our study except PCT had a role in the discrimination of IDFU. Contrary to our study, in the study performed by Uzun et al. ${ }^{[13]}$, the highest discriminatory power was defined for PCT in the diagnosis of IDFU. In another study performed by Jonaidi Jafari et al. ${ }^{[10]}$ who evaluated the role of serum PCT levels in the discrimination of IDFU and NIDFU, sensitivity and specificity were determined to be $70 \%$ and $74 \%$, respectively, for $0.21 \mathrm{ng} / \mathrm{mL}$ value of PCT. However, in the same study, the marker with the highest discriminatory power for IDFU and NIDFU was ESR and it was followed by CRP, PCT, and WBC. The authors state that serum PCT levels may have a role in the discrimination of IDFU in the case of the combination of markers like ESR and CRP ${ }^{[10]}$. Similarly, in another study performed by Massara et al. ${ }^{[14]}$, the authors stated that the highest sensitivity and specificity in the discrimination of IDFU and NIDFU could be provided with a combination of at least two markers (CRP and PCT or ESR and PCT). Also in the study performed by Jeandrot et al. ${ }^{[11]}$ evaluating the role of serum CRP and PCT levels in the discrimination of mildly infected and non-infected diabetic foot ulcer, the highest AUC value was obtained with the combination of CRP and PCT.

In the majority of these studies evaluating the role of serum PCT levels, the patients not receiving antibiotic 6 months before admission were included in the study. When considering the natural history of IDFU in clinical practice, this is not a frequently encountered condition. In a review, the role of serum PCT levels in the discrimination of IDFU was evaluated and it was stated that the studies were heterogeneous and the patients receiving an antibiotic within the last 6 months were excluded in many of them. They also stated that serum PCT levels might have a potential role in the discrimination of IDFU but it could not discriminate severe infection from less severe infection ${ }^{[22]}$. Also in another review evaluating IDFU, it was stated that in the absence of systemic manifestations of localized infection, serum PCT levels could not discriminate acute infection from acute ischemia or noninfectious conditions or osteomyelitis from soft tissue infections ${ }^{[23]}$. Serum PCT levels have some limitations such as the following: they cannot be studied in the laboratory of many hospitals and they are expensive markers, able to show change according to age, pathogen, and type of infection ${ }^{[9]}$. Further studies are required for routine use of serum PCT levels in IDFU diagnosis.

As far as the literature can be reviewed so far, there are only two studies related to the use of serum IL-6 levels in IDFU diagnosis. The first one was a study including also type 1 diabetes patients; it was determined in this study that serum IL-6 levels were effective in ulcer classification according to Texas classification but it was not an independent variable for the determination of infection severity ${ }^{[18]}$.

The second one was a study including only the patients with IDFU; it was determined in this study that serum IL-6 levels were increased in correlation with CRP and the other inflammatory markers and serum IL-6 levels were decreased in the patients recovered with antibiotic treatment. However, this study includes only the patients followed up with the diagnosis of IDFU, and since there is no control group, it is not possible to compare baseline serum IL-6 levels of the IDFU group and the NIDFU group ${ }^{[15]}$. As far as the literature could be evaluated, it was shown for the first time in our study that serum IL-6 levels were effective for the discrimination of infected and non-infected ulcer in a study including only type 2 diabetes patients. While this shows us that serum IL-6 levels might have a role in the diagnosis of IDFU, since the number of studies related to serum IL-6 levels is extremely limited, further studies are required.

CRP is an acute phase reactant whose levels elevate during inflammatory processes occurring in the body; elevated serum CRP levels can also be detected in the conditions not caused by bacterial infection ${ }^{[13]}$. In a study performed, elevated serum CRP levels were determined in diabetic patients compared to nondiabetic patients and again in the patients with DFU compared to the patients without DFU. However, in this study, serum CRP levels were not found to be statistically significant especially in the discrimination of IDFU and NIDFU ${ }^{[14]}$. On the contrary, in our study, serum CRP level is the inflammatory marker which has the highest discriminatory power in the discrimination of IDFU and NIDFU. In harmony with our study, serum CRP level was determined to be the inflammatory marker with the highest discriminatory power in the discrimination of mildly IDFU and NIDFU ${ }^{[11]}$. In another study indicating that serum CRP levels were more effective than the other inflammatory markers, 123 IDFUs were evaluated and the roles of serum PCT and CRP levels in IDFU were evaluated and only serum CRP levels were found to be effective in grading the severity of the infection ${ }^{[24]}$.

There are some limitations in our study; since anaerobic culture was not accessible in diabetic research hospital, anaerobic pathogens were not studied in diabetic foot ulcers. Also, the diagnosis of osteomyelitis in our study was based on imaging reports rather than bone biopsy, which is a more definite diagnostic method.

As a result, serum CRP, ESR, IL-6, and WBC levels were determined to be useful parameters in the diagnosis of IDFU in our study. Serum PCT levels were not found to be effective in the discrimination of IDFU and NIDFU. Serum IL-6 levels seem to be two promising inflammatory markers in the discrimination of IDFU. The efficiency of serum IL-6 levels for the discrimination of infected and non-infected ulcer in infections of ulcers associated with type 2 diabetes was shown for the first time in our study. Since serum IL-6 levels have been used in a limited number of studies, further studies are required in order to understand its role in the diagnosis of IDFU.

\section{Conclusion}

PCT appears to be a reliable marker of acute DFI and a better predictor of clinical outcome than the existing markers, ESR, CRP, and WBC count. Along with the clinical prognosis predictors such as gangrene and sepsis, elevated PCT should be useful for clinicians in prognosticating clinical outcome, decision making as well as managing patients with acute DFIs.

\section{Ethics approval and consent to participate}

The study protocol was approved by the medical ethics committee of the Rajasthan University of Health Sciences, Jaipur, Rajasthan(State), India.

\section{Financial support and sponsorship}

No financial support from an external agency was used for this study.

\section{Conflicts of interest}


There are no conflicts of interest.

\section{Acknowledgements}

This work was supported by Dr.R.P.Agarwal, Principal \& Controller, S.P. Medical College, \& Hospital, Bikaner. Dr.Surendra Kumar, Sr. Professor, Principal Investigator. The authors are grateful to Sr. Professor for her helps in scientific discussion and takes responsibility for the integrity of the data and the accuracy of the data analysis.

*Corresponding Author: Dr. Dinesh Parmar; Associate Professor, Department of Medicine, Govt. Medical College, Barmer, Rajasthan 344001, India;

\section{References}

[1] B. A. Lipsky, A. R. Berendt, P. B. Cornia et al., "2012 Infectious Diseases Society of America clinical practice guideline for the diagnosis and treatment of diabetic foot infections," Clinical Infectious Diseases, vol. 54, pp. 132-173, 2012.

[2] D. G. Armstrong, J. Wrobel, and J. M. Robbins, "Guest editorial: are diabetes-related wounds and amputations worse than cancer?," International Wound Journal, vol. 4, no. 4, pp. 286- 287, 2007.

[3] N. C. Schaper, J. J. Van Netten, J. Apelqvist, B. A. Lipsky, K. Bakker, and International Working Group on the Diabetic Foot, "Prevention and management of foot problems in diabetes: a Summary Guidance for Daily Practice 2015, based on the IWGDF Guidance Documents," Diabetes Metabolism Research and Reviews, vol. 32, Supplement S1, pp. 7-15, 2016.

[4] L. A. Lavery, D. G. Armstrong, D. P. Murdoch, E. J. Peters, and B. A. Lipsky, "Validation of the Infectious Diseases Society of America's diabetic foot infection classification system," Clinical Infectious Diseases, vol. 44, no. 4, pp. 562-565, 2007.

[5] D. K. Wukich, K. B. Hobizal, and M. M. Brooks, "Severity of diabetic foot infection and rate of limb salvage," Foot \& Ankle International, vol. 34, no. 3, pp. 351-358, 2013.

[6] A. H. Widatalla, S. E. Mahadi, M. A. Shawer, H. A. Elsayem, and M. E. Ahmed, "Implementation of diabetic foot ulcer classification system for research purposes to predict lower extremity amputation," International Journal of Diabetes in Developing Countries, vol. 29, no. 1, pp. 1-5, 2009.

[7] N. C. Schaper, "Diabetic foot ulcer classification system for research purposes: a progress report on criteria for including patients in research studies," Diabetes/Metabolism Research and Reviews, vol. 20, pp. S90-S95, 2004.

[8] J. Aragón-Sánchez, "Seminar review: a review of the basis of surgical treatment of diabetic foot infections," The International Journal of Lower Extremity Wounds, vol. 10, no. 1, pp. 33-65, 2011.

[9] N. Jonaidi Jafari, M. Safaee Firouzabadi, M. Izadi, M. S. Safaee Firouzabadi, and A. Saburi, "Can procalcitonin be an accurate diagnostic marker for the classification of diabetic foot ulcers?," International Journal of Endocrinology and Metabolism, vol. 12, article e13376, 2014.
[10] L. Simon, F. Gauvin, D. K. Amre, P. Saint-Louis, and J. Lacroix, "Serum procalcitonin and C-reactive protein levels as markers of bacterial infection: a systematic review and meta-analysis," Clinical Infectious Diseases, vol. 39, no. 2, pp. 206-217, 2004.

[11] A. Jeandrot, J. L. Richard, C. Combescure et al., "Serum procalcitonin and C-reactive protein concentrations to distinguish mildly infected from non-infected diabetic foot ulcers: a pilot study," Diabetologia, vol. 51, no. 2, pp. 347-352, 2008.

[12] G. Uzun, E. Solmazgul, H. Curuksulu et al., "Procalcitonin as a diagnostic aid in diabetic foot infections," The Tohoku Journal of Experimental Medicine, vol. 213, no. 4, pp. 305-312, 2007.

[13] M. Massara, G. De Caridi, R. Serra et al.,"The role of procalcitonin as a marker of diabetic foot ulcer infection," International Wound Journal, vol. 14, no. 1, pp. 31-34, 2017.

[14] F. A. Altay, İ. Sencan, "Does treatment affect the levels of serum interleukin-6, interleukin- 8 and procalcitonin in diabetic foot infection? A pilot study," Journal of Diabetes and its Complications, vol. 26, no. 3, pp. 214 218, 2012.

[15] C. Buck, J. Bundschu, H. Gallati, P. Bartmann, and F. Pohlandt, "Interleukin-6: a sensitive parameter for the early diagnosis of neonatal bacterial infection," Pediatrics, vol. 93, no. 1, pp. 54-58, 1994.

[16] R. C. Silveira and R. S. Procianoy, "Evaluation of interleukin- 6 , tumour necrosis factor- $\alpha$ and interleukin$1 \beta$ for early diagnosis of neonatal sepsis," Acta Paediatrica, vol. 88, no. 6, pp. 647-650, 1999.

[17] C. Weigelt, B. Rose, U. Poschen et al.,"Immune mediators in patients with acute diabetic foot syndrome," Diabetes Care, vol. 32, no. 8, pp. 1491-1496, 2009.

[18] M. W. Mosesson, K. R. Siebenlist, and D. A. Meh,"The structure and biological features of fibrinogen and fibrin," Annals of the New York Academy of Sciences, vol. 936, pp. 11-30, 2001.

[19] X. H. Li, L. Y. Guan, H. Y. Lin et al.,"Fibrinogen: a marker in predicting diabetic foot ulcer severity," Journal of Diabetes Research, vol. 2016, Article ID 2358321, 5 pages, 2016.

[20] M. L. Grayson, G. W. Gibbons, K. Balogh, E. Levin, and A. W. Karchmer,"Probing to bone in infected pedal ulcers. A clinical sign of underlying osteomyelitis in diabetic patients," Journal of the American Medical Association, vol. 273, no. 9, pp. 721-723, 1995.

[21] K. Saeed, N. Ahmad, and M. Dryden, "The value of procalcitonin measurement in localized skin and skin structure infection, diabetic foot infections, septic arthritis and osteomyelitis," Expert Review of Molecular Diagnostics, vol. 14, no. 1, pp. 47-54, 2014.

[22] A. W. Glaudemans, I. Uçkay, and B. A. Lipsky,"Challenges in diagnosing infection in the diabetic foot," Diabetic Medicine, vol. 32, no. 6, pp. 748-759, 2015.

[23] R. Rattan and D. Nayak, "High levels of plasma malondialdehyde, protein carbonyl, and fibrinogen have prognostic potential to predict poor outcomes in patients with diabetic foot wounds: a preliminary communication," The International Journal of Lower Extremity Wounds, vol. 7, no. 4, pp. 198-203, 2008. 
[24] J. H. Park, D. H. Suh, H. J. Kim, and G. W. Choi, "Role of procalcitonin in infected diabetic foot ulcer," Diabetes Research and Clinical Practice, vol. 128, pp. 51-57, 2017.

[25] Abbas M, Uckay I, Lipsky BA. In diabetic foot infections antibiotics are to treat infection, not to heal wounds. Expert Opin Pharmacother 2015; 16:821-832.

[26] Singh S, Pai DR, Yuhhui C. Diabetic foot ulcer diagnosis and management. Clin Res Foot Ankle 2013; $1: 120$.

[27] Saleem SM, Khan SS, Jan SS. Role of serum procalcitonin level in early diagnosis of bacterial pneumonia in children, a hospital-based study. Int J Res Med Sci 2016; 4:1518-1521.
Open Access This article is licensed under a

Creative Commons Attribution 4.0

International License, which permits use, sharing, adaptation, distribution and reproduction in any medium or format, as long as you give appropriate credit to the original author(s) and the source, provide a link to the Creative Commons license, and indicate if changes were made. The images or other third party material in this article are included in the article's Creative Commons license, unless indicated otherwise in a credit line to the material. If material is not included in the article's Creative Commons license and your intended use is not permitted by statutory regulation or exceeds the permitted use, you will need to obtain permission directly from the copyright holder. To view a copy of this license, visit https://creativecommons.org/licenses/by/4.0/.

(c) The Author(s) 2021 